\title{
Sedimentary Petrographic Study of Tephra, Glacial and Aeolian Grains in a Quaternary Paleosol Sequence on Mount Kenya, East Africa William \\ Étude de la pétrographie sédimentaire des grains d'origines volcanique, glaciaire et éolienne provenant d'une séquence de paléosols quaternaires sur le mont Kenya, Afrique de l'Est Sedimentpetrographische Studie vulkanischer Asche, glazialer und äolischer Körner in einer Folge quartärer Paläoböden am Mt. Kenya, Ostafrika
}

\author{
William C. Mahaney, Walter Vortisch et Klaus Fecher
}

Volume 42, numéro 2, 1988

URI : https://id.erudit.org/iderudit/032720ar

DOI : https://doi.org/10.7202/032720ar

\section{Aller au sommaire du numéro}

\section{Éditeur(s)}

Les Presses de l'Université de Montréal

\section{ISSN}

0705-7199 (imprimé)

1492-143X (numérique)

Découvrir la revue

\section{Citer cet article}

Mahaney, W. C., Vortisch, W. \& Fecher, K. (1988). Sedimentary Petrographic Study of Tephra, Glacial and Aeolian Grains in a Quaternary Paleosol Sequence on Mount Kenya, East Africa William. Géographie physique et Quaternaire, 42(2), 137-146. https://doi.org/10.7202/032720ar
Résumé de l'article

Les grains d'origines volcanique, éolienne et glaciaire d'une séquence lithostratigraphique de paléosols ont été étudiés en vue de déterminer si leurs propriétés pétrographiques pouvaient fournir des témoignages des différents paléoenvironnements qui se sont succédé à partir d'environ 100000 jusqu'à 500000 BP. Dans la séquence, du till renfermant de grandes quantités de minéraux ferromagnétiques alterne avec des sédiments éoliens et volcaniques renfermant beaucoup de verres volcaniques, de quartz et de feldspaths plus ou moins corrodés. Le quartz, un minéral allochtone, vraisemblablement d'abord d'origine éolienne, a aussi connu un transport par les glaces qui en ont broyé les surfaces. La comparaison des dépôts d'altération dans les deux paléosols indique que les conditions de précipitations et du drainage étaient très différentes au cours de la formation de ces deux paléosols interglaciaires. 


\section{SEDIMENTARY PETROGRAPHIC STUDY OF TEPHRA, GLACIAL AND AEOLIAN GRAINS IN A QUATERNARY PALEOSOL SEQUENCE ON MOUNT KENYA, EAST AFRICA*}

William C. MAHANEY, Walter VORTISCH and Klaus FECHER: first author, Department of Geography, Atkinson College, York University, 4700 Keele Street, North York, Ontario M3J 1P3; second and third authors, Institut für Geologie und Palaontologie, Universität Marburg, D-3550 Marburg/Lahnberge, Bundersrepublik Deutschland.

\begin{abstract}
Tephra, aeolian and glacial grains in a lithostratigraphic-paleosol sequence on Mount Kenya were studied to determine if their petrographic properties would provide evidence for different paleoenvironments over the period of $\sim 100,000$ to $\sim 500,000 \mathrm{yr}$ BP. Till containing high quantities of ferromagnetic minerals alternate in the sequence with aeolian sediments and tephras containing an abundance of volcanic glass, quartz, and feldspars with variable degrees of etching. Quartz, an allochthonous mineral on Mount Kenya, appears to have an aeolian origin followed by ice transport which produced glacially-crushed surfaces. A comparison of weathering products in the two paleosols leads to the conclusion that precipitation-drainage conditions were quite different during the formation of these interglacial paleosols.
\end{abstract}

RÉSUMÉ Étude de la pétrographie sédimentaire des grains d'origines volcanique, glaciaire et éolienne provenant d'une séquence de paléosols quaternaires sur le mont Kenya, Afrique de l'Est. Les grains d'origines volcanique, éolienne et glaciaire d'une séquence lithostratigraphique de paléosols ont été étudiés en vue de déterminer si leurs propriétés pétrographiques pouvaient fournir des témoignages des différents paléoenvironnements qui se sont succédé à partir d'environ 100000 jusqu'à 500000 BP. Dans la séquence, du till renfermant de grandes quantités de minéraux ferromagnétiques alterne avec des sédiments éoliens et volcaniques renfermant beaucoup de verres volcaniques, de quartz et de feldspaths plus ou moins corrodés. Le quartz, un minéral allochtone, vraisemblablement d'abord d'origine éolienne, a aussi connu un transport par les glaces qui en ont broyé les surfaces. La comparaison des dépôts d'altération dans les deux paléosols indique que les conditions de précipitations et du drainage étaient très différentes au cours de la formation de ces deux paléosols interglaciaires.
ZUSAMMENFASSUNG Sedimentpetrographische Studie vulkanischer Asche, glazialer und äolischer Körner in einer Folge quartärer Paläoböden am Mt. Kenya, Ostafrika. Zwei quartäre Paläoböden, die insgesamt einem Zeitraum von etwa 500000 bis $100000 \mathrm{~J}$. v. h. entsprechen, wurden im Hinblick auf ihre Bildungs bedingungen untersucht. In der Abfolge wechsellagern Moränen mit glasreichen vulkanischen Aschen und äolischen Sedimenten. Die Moränen weisen relativ hohe Gehalte an ferromagnetischen Mineralen (vorallem Magnetit) auf. Die äolischen Sedimente führen neben reichlich Glas und Feldspäten (Intensität der Lösungsverwitterung variabel) auch verhältnismäßig viel Quarz. Quarz ist am Mt. Kenya allochthon. Er scheint äolischen Ursprungs zu sein. Für Eistransport typische Bruchflächen beweisen seine Umlagerung durch Gletschereis. Ein Vergleich der Verwitterungsprodukte zeigt, daß die Niederschlagsund Drainagebedingungen bei der Bildung der beiden Paläoböden deutlich verschieden waren.

\footnotetext{
* Contribution du premier symposium de la CANQUA sous la direction de René W. Barendregt.

Manuscrit reçu le 30 décembre 1986; manuscrit révisé accepté le 2 décembre 1987.
} 


\section{INTRODUCTION}

Located near the equator $175 \mathrm{~km}$ north of Nairobi, Mount Kenya forms one of the major high mountains in East Africa (Fig. 1). Approximately $100 \mathrm{~km}$ in diameter, this stratotype volcano rises to $5199 \mathrm{~m}$, and contains a sequence of Pleistocene glacial and nonglacial deposits previously described by Nilsson (1935) and Baker (1967). More recently, the glacial stratigraphy was refined by Mahaney, first by reconnaissance studies $(1972,1979)$ and later by more detailed investigations (1981, 1982, 1984a, 1984b, 1984c, 1985, and 1987). As a result deposits involved in this study, first described over fifty years ago as belonging to the "older glaciation" of Nilsson (1935), are regarded now as antedating the last glaciation. Mahaney (1982) discovered that the older glaciation type section actually consisted of more than one till, and accordingly he subdivided it into two drifts - Teleki Till and pre-Teleki Till - separated by loesses and tephras. The resulting paleosol descriptions, lithostratigraphy, and paleoenvironmental interpretations of the fine and very fine sand grains $(250-63 \mu \mathrm{m})$ are the subject of this paper.

In comparing the two paleosols described here it is important to determine if pedological differences result mainly from the lithology or from paleoweathering (especially changes in precipitation which may influence drainage conditions). To make these determinations it is important to study the primary mineralogy of detrital grains as well as weathering products on grain surfaces. Moreover, the complex interplay between volcanoclastic/sedimentary activity and soil-forming processes has led to the development of important paleosols before and after the Teleki Glaciation (equivalent to Illinoian in North America). An assessment of the relative degrees of development of these paleosols will provide important information on the paleoclimate that existed during the time of their formation.

\section{FIELD AREA}

Profile TV23 (Fig. 1) is located in an end moraine ridge at $2980 \mathrm{~m}$ at the type locality for Teleki and pre-Teleki tills
(Mahaney, 1982, 1984a). The paleosols described herein are formed in the upper $4 \mathrm{~m}$ of a sequence of Quaternary deposits estimated to be $\sim 30 \mathrm{~m}$ deep and overlying bedrock with a phonolitic composition.

The dominant vegetation of the bamboo forest/Hagenia woodland consists of Arundinaria alpina and Hagenia abyssinica (Hedberg, 1964; Coe, 1967) (Fig. 2). Ground vegetation is sparse, estimated at $30 \%$ cover, and consists of scattered Cyperus rotundifolius, species of Carex, and clusters of $\mathrm{Ly}$ copodium saururus and Dryopteris inaequalis. Climate in the field area is not known with precision; however, at Naro Moru $(2000 \mathrm{~m})$ precipitation increases from $500 \mathrm{~mm}$ to $\sim 1000 \mathrm{~mm}$ on the high moorland in the lower Afroalpine zone ( $3500 \mathrm{~m})$ (Coetzee, 1967). While evapotranspiration data are not available, moist soil colors (5YR), dense forest cover, and leaching effects in the upper $0.5 \mathrm{~m}$ of profile TV23 suggest that there is no dry season (Mahaney and Boyer, 1986). Temperature



FIGURE 2. Hagenia woodland/bamboo forest transiton zone, Naro Moru River Basin, Mount Kenya. The road follows the margin of Naro Moru Till (lower Brunhes in age).

Zone de transition entre la région boisée (Hagenia) et la forêt de bambou, bassin de la rivière Naro Moru, mont Kenya. La route suit la limite du Till de Naro Moru (Brunhes inférieur).

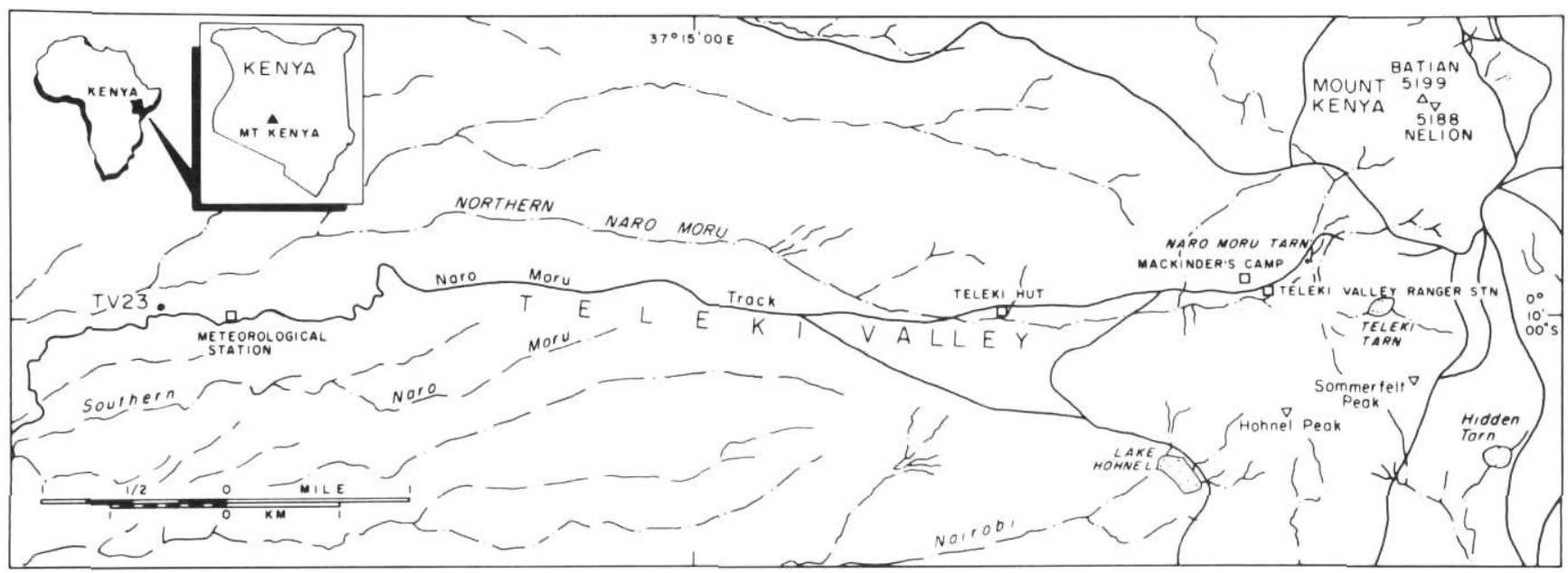

FIGURE 1. Location of site TV23, Naro Moru River Basin, Mount Kenya.

Localisation du site $n^{\circ}$ TV23, bassin de la rivière Naro Moru, mont Kenya. 
extrapolations (Coe, 1967; Pedgley, 1966; Thompson, 1966) suggest that the mean annual temperature at this site approximates $+7.2^{\circ} \mathrm{C}$, with extremes of $+19^{\circ} \mathrm{C}$ and $-1.6^{\circ} \mathrm{C}$. Soil moisture may be sufficient to move some fine grained material such as clay and silt downward in the profile; however, in this study sand $(63-250 \mu \mathrm{m})$ is not considered likely to respond to downward movement of water, making it the most useful fraction to study in situ mineralogy and lithostratigraphy.

\section{METHODS}

Paleosol descriptions follow the Soil Survey Staff (1951, 1975) and Birkeland (1984). Particle size analysis for sand separates follows the Wentworth scale of Folk (1968). Particle size separations were made by wet sieving the fine fractions (silt plus clay) and dry sieving the sands (Bouyoucos, 1962; Day, 1965). The sand and clay samples were studied with the aid of X-ray diffractometry (XRD, representative powder mounts), polarizing microscope (representative grain mounts), and scanning electron microscope (SEM). Moreover, the ferromagnetic fraction of each sample was separated with a hand magnet, weighed with an analytical balance, and calculated as weight-percent (first column, Fig. 3). The results of the light-microscopical analysis (in the mean about 300 grains determined per mount) are given as grain percents (Fig. 3). Corrosion of some primary minerals (especially feldspar) and neoformation of clay minerals were studied by SEM.

\section{RESULTS}

The polarizing microscope, XRD, and SEM (Figs. 3-11) were used to determine amounts of feldspar, quartz, magnetite, and amphibole. A few grains of nepheline were identified by light microscope in most of the samples; however, the amount is too small for XRD identification. In addition, a few grains of accessory minerals (e.g. biotite, garnet) were found with angular to subangular shapes, especially in the tills. Volcanic glass and its alteration products were classified by aid of the petrographic microscope. The minerals, glass types, and some alteration-products, as shown in Figure 3, represent more than 90 per cent (weight + grain per cent) of each sample.

Feldspar in these samples is made up predominantly of sanidine, but plagioclases (in part polysynthetic twins) also occur in small amounts (Figs. 4, 5, and 6). In all samples some grains are corroded, but there are also fresh grains that do not show etching features (Fig. 4A); these occur mainly in the younger loesses of the post-Teleki paleosol. In contrast to considerable surface corrosion nearly all feldspar grains are internally fresh in both paleosols. Generally, feldspar corrosion was not intensive enough to alter the grain percentages significantly due to complete dissolution. The amount of residual clay minerals on corrosion surfaces of feldspar grains (see Fig. 11) is small. Feldspar dissolution seems to have produced considerable corrosion but with relatively little in situ clay mineral formation.

Quartz grains with inclusions appear to be predominantly of volcanic and/or hydrothermal origin (see SEM micrographs, Fig. 7). An abnormally high relative intensity of the 100 reflection of quartz in several samples indicates an important proportion of secondary, fine grain (chalcedonic) low-temperature quartz (Eslinger et al., 1973). Rarely observed under the polarizing microscope, this type of quartz occurs mainly in devitrified volcanic glass.

Magnetite, which is the predominant part of the "ferromagnetic fraction", is generally unweathered and frequently forms typical octahedral crystals. But it is also represented as zenomorphic particles. Amphibole (hornblende) occurs with a few grains only per grain mount. It appears in trace amounts in a few $\mathrm{X}$-ray diffraction patterns which may result from microliths in volcanic glass. It is noteworthy that amphibole and biotite grains (the latter very rare) generally are unweathered; biotite is found mainly in eolian parent materials.



FIGURE 3. Lithostratigraphy, paleosol sequence (A), and mineralogy ( $B$ and $C$ ) of the fine and very fine sand fractions $(63-250 \mu \mathrm{m})$ in profile TV23 on Mount Kenya (modified from Fig. 2 in Vortisch et al., 1987).
Lithostratigraphie, séquence de paléosols $(A)$ et minéralogie ( $B$ et C) des fractions fines et très fines $(63-250 \mu \mathrm{m})$ du profil TV23 sur le mont Kenya (modifié à partir de la fig. 2 de Vortisch et al., 1987). 

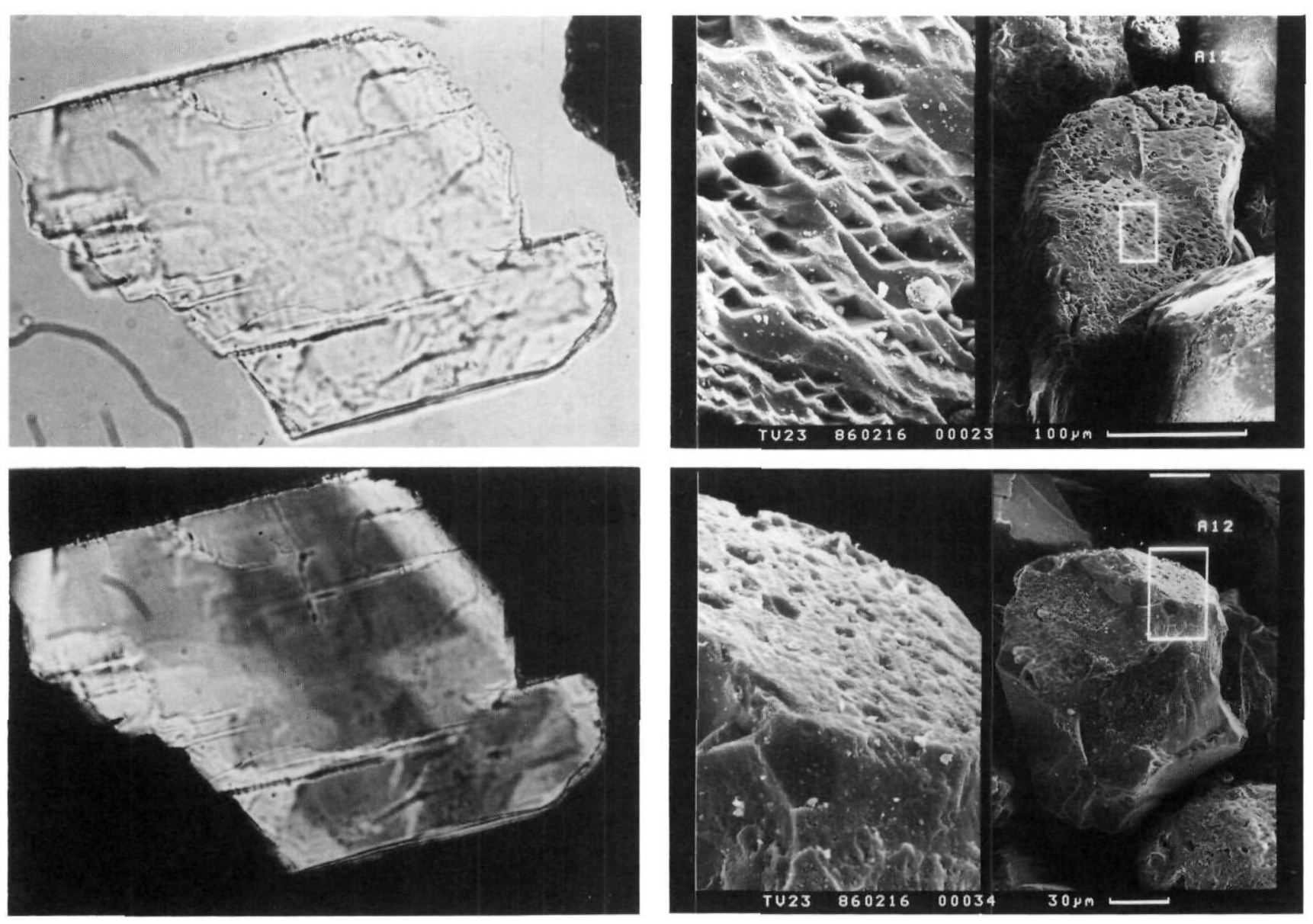

FIGURE 4. Fine and very sand fraction in the $A 12$ horizon of the post-Teleki paleosol A; B: Initial stage of weathering of an alkali feldspar. Weathering occurs as dissolution parallel to cleavage planes (A: 1 nicol, scale $=125 \mu \mathrm{m} ; \mathrm{B}$ : crossed nicols). C: SEM micrographs of etched alkali feldspar (cf. Fig. 4). D: SEM micrograph of a quartz grain with an old etched surface, combined with unweathered surfaces, probably produced by glacial crushing. The combination of the different surfaces indicates glacial redeposition of that grain from an older paleosol.

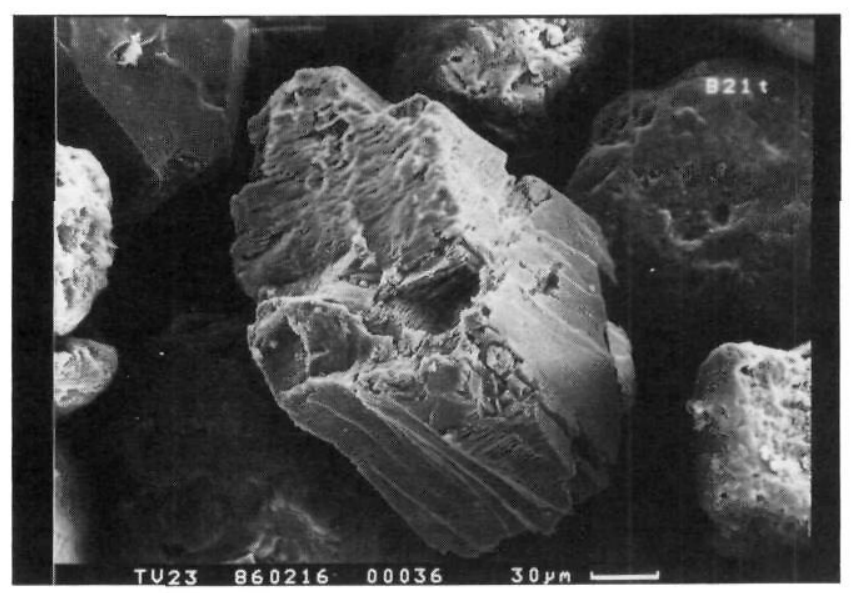

Fractions fines et très fines du sable de l'horizon A 12 du paléosol post-Teleki. A; B: Staďe initial d'altération d'un feldspath alcalin. L'altération se présente comme une dissolution parallèle aux plans de clivage ( $A: 1$ nicol, échelle $=125 \mu \mathrm{m} ; B$ : nicols croisés). $C$ : Micrographe d'un feldspath alcalin corrodé (voir la fig. 4). D: Micrographe d'un grain de quartz dont la surface présente une marque de corrosion ancienne, probablement due à un broyage par la glace. La combinaison des différentes surfaces montre que le grain a été remanié par les glaces à partir d'un paléosol plus ancien.



A: Micrographe d'un feldspath alcalin davantage altérée et dont la composition chimique est à peu près la même que le feldspath de la figure 4C; horizon B2 It, paléosol post-Teleki. B: détail de A, au centre. 

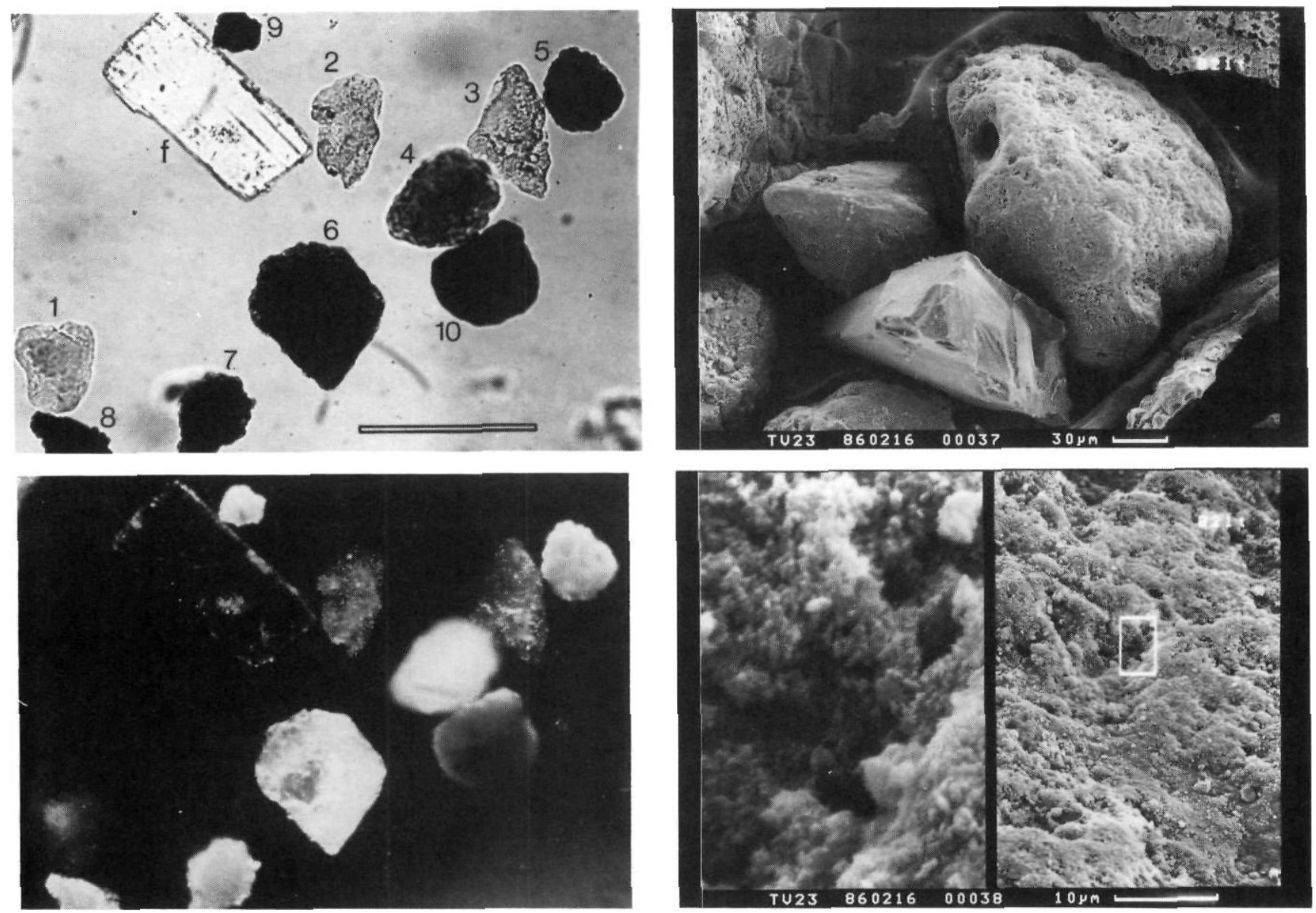

FIGURE 6. ALkali feldspar (f) with initial dissolution parallel to cleavage planes, and volcanic glass of different weathering stages in the B2 It horizon of the post-Teleki paleosol. 1-3: unweathered transparent glass; 4-9: transparent glass with varying degree of weathering ( = "altered glass" in Fig. 3; in situ color in nature yellowishbrown, i.e. "limonitic"); $10=$ opaque glass with an early stage of weathering. A: normal transmitted light (1 nicol, scale $=250 \mu \mathrm{m})$; B: oblique reflected light.

Feldspath alcalin (f) montrant un début de dissolution parallèle au plan de clivage, et verre volcanique à différents stades d'altération dans l'horizon B2 It du paléosol post-Teleki. 1-3: verre volcanique inaltéré; 4-9: verre transparent présentant divers degrés d'altération (verre altéré de la fig. 3; dans la nature, jaune-brun, c.-à-d. "limonitique»); 10: verre opaque présentant un premier stade d'altération A: transmission normale de la lumière (1 nicol, échelle $=250 \mu \mathrm{m}$ ) $B$ : transmission oblique de la lumière.

Volcanic glass is grouped into two types (see Fig. 6):

a) transparent to translucent, often inclusion-rich, and varying from nearly colorless to brownish colors (transparent glass in Figs. 3, 6 and 8).

b) opaque grains ("droplets") with dark brown to black colors, "sideromelane" (Heiken, 1972), the outermost part of such grains are often faintly translucent (opaque glass in Figs. 3 and 6).

All grains of volcanic glass studied have refractive indices considerably above 1.54 and are therefore considered basic in composition (according to Bambauer et al., 1971, leucite tephritic to basaltic). All transitional stages between unweath-
FIGURE 7. SEM micrograph of weathered volcanic glass (right, centre), and glacially crushed quartz (below, centre), in the B2 It horizon of the post-Teleki paleosol (A.). The surface of the glass particle consists mainly of metahalloysite (partly with tubular habit) and a small amount of iron compounds (B: $10 \mu \mathrm{m}$-scale is valid for the right part). The diameter of individual clay particles is predominantly between 0.05 and $0.2 \mu \mathrm{m}$.

Micrographe de verre volcanique altéré (centre droit) et quartz broyé par la glace (centre inférieur) dans l'horizon B2 It du paléosol postTeleki (A). La surface de la particule de verre est en grande partie constituée de métahalloysite (partiellement de forme tubulaire) et une petite quantité de composés de fer (B: échelle de $10 \mu \mathrm{m}$ vaut pour la partie droite). Le diamètre des particules d'argile se situe entre 0,05 et $0,2 \mu \mathrm{m}$.

ered and weathered/altered volcanic glass were observed. Glass of type a tends to be transformed to limonitic oxidized grains, becoming more opaque with increasing weathering. This weathering product is called altered glass in Figure 3 and it seems to be in the main responsible for halloysite formation.

Hematitic oxidized grains (Fig. 3) represent alteration products, which are \pm opaque and seem to include predominantly alteration products of glass type b. In most cases, both alteration products can be differentiated easily under the microscope using reflected light. However, with the combination of hematic and limonitic components, a minority of grains are difficult to classify. 
Metahalloysite (primarily formed as halloysite) and gibbsite, identified by means of XRD and SEM, are the most important waethering products. They are essentially formed on particles of volcanic glass (Figs. 7-10). The distribution of halloysite/ metahalloysite correlates with altered glass (Fig. 3). (For further mineralogical details see Vortisch et al., 1987.)

\section{DISCUSSION}

\section{LITHOSTRATIGRAPHY}

Profile TV23 may be subdivided into at least five lithologic units (Fig. 3):

Unit l: (from above) represents both volcanic ash and eolian material. The eolian origin is inferred from high amounts of quartz, as discussed by Mahaney (1984b). Unit I shows distinct variations that may suggest its further subdivision (see discussion of soil sub-units below: Fig. 3).

Unit II: represents Teleki-Till which is very different from the units above and below (e.g. high feldspar and magnetite contents, Fig. 8).

Unit III: consists of layers of very pure volcanic ashes (vitric tuffs; Fig. 9). The abrupt change of the glass type ratio indicates the presence of at least two different tuffs (subunits IIla and IIIb).

Unit IV: consists of a mixture of volcanic ash and eolian sediments (relative high quartz content) (Fig. 10).
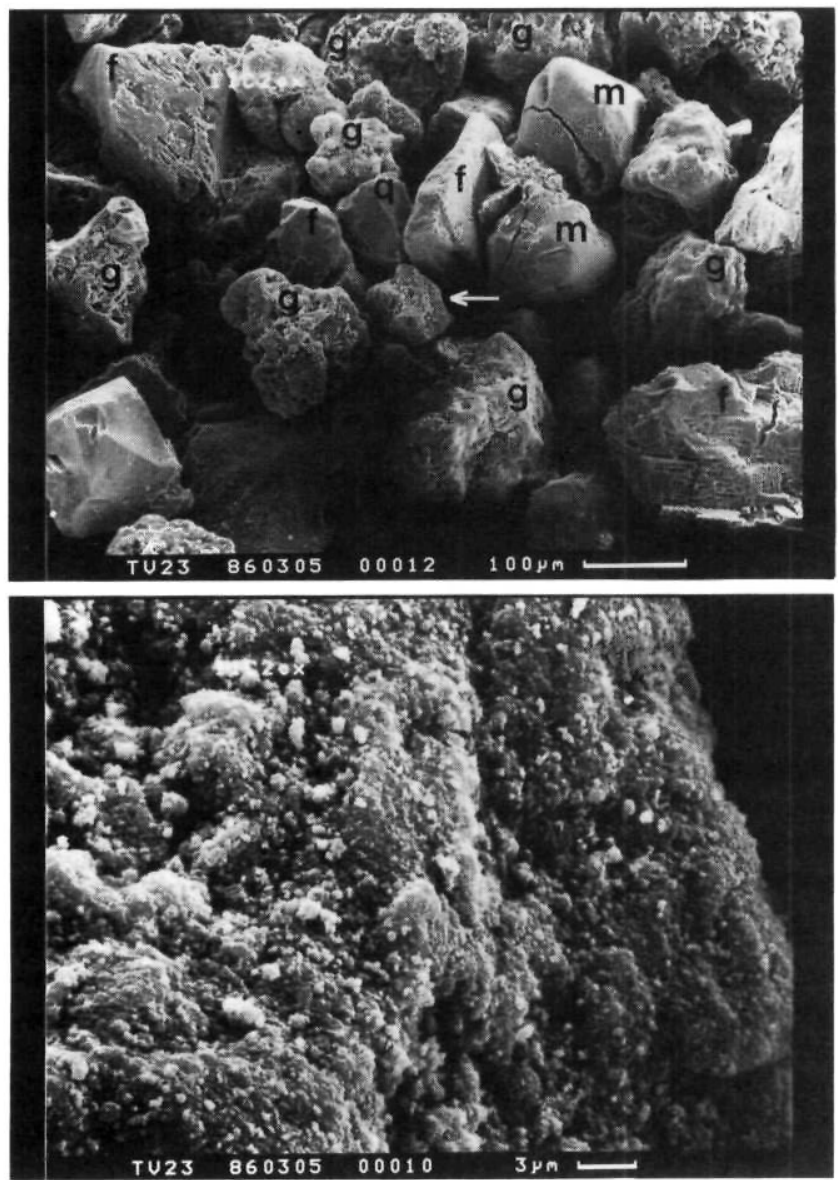

Unit $V$ : is differentiated from Unit IV mainly by its high proportion of ferromagnetic material (mainly magnetite) (Figs. 3 and 11). This bed is similar to Unit II (Teleki Till); however, the high quartz content suggests an eolian influence. Unit $\mathrm{V}$ may represent a till (pre-Teleki Till) that reworked eolian sediments during glacial transport. A downward displacement of eolian material by water and/or biological processes (bioturbation) during the pre-Teleki/Teleki Interglacial might be another plausible explanation for the presence of quartz in pre-Teleki Till (see Mahaney and Boyer, 1986).

This compound paleosol profile clearly shows distinct primary lithologic boundaries (especially volcanic glass types and average content of feldspar) coinciding with the boundary between the two main paleosol units (post- and pre-Teleki paleosols).

\section{ORIGIN OF SAND GRAINS}

In the post-Teleki and pre-Teleki paleosols quartz appears to be the main indicator of airfall influxes of material (Units I and III). Over half the quartz grains are glacially crushed, indicating that they were reworked from glacial deposits by aeolian processes. Feldspar, on the other hand, varies considerably between the pre-Teleki (Unit IV) and Teleki (Unit IV) and Teleki (Unit II) tills with lower percentages ( 20\%) in the pre-Teleki paleosol, and higher values in the post-Teleki paleosol. In the tills feldspar grains have angular to subangular shapes, whereas in the loesses (Units I and III) shape is

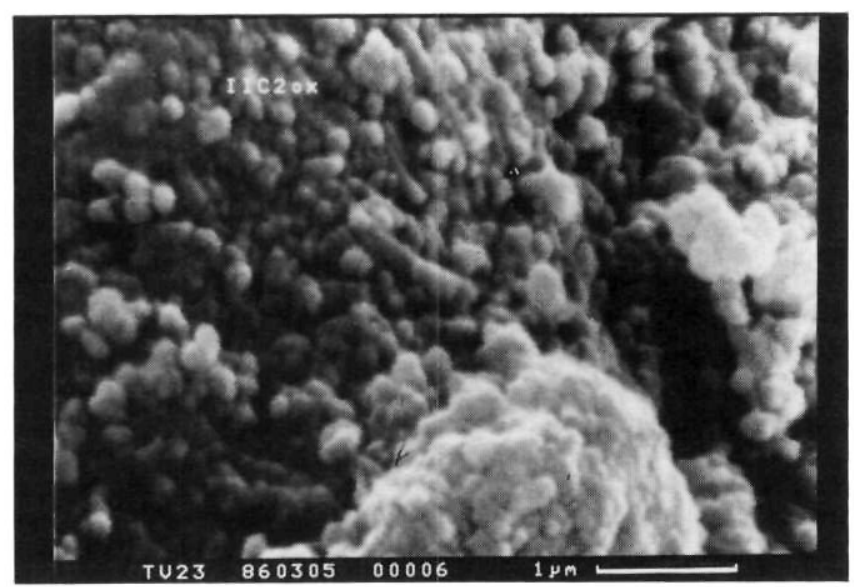

FIGURE 8. Almost unweathered to rather intensively etched alkali feldspar $(f)$, magnetite $(m)$, volcanic glass of different weathering stages (g) and quartz (q). Arrow: weathered glass particle, consisting predominantly of gibbsite. B-C: detail of gibbsitic glass particle in the centre of $A(C$ : centre of $B)$. According to energy dispersive analysis, the area shown in these micrographs consists of a mixture of gibbsite and metahalloysite with a gibbsite/metahalloysite ratio of about 3:1. The proportion of iron compounds is below $10 \%$.

Feldspath alcalin (f) plus ou moins altéré, magnétite $(m)$, verre volcanique à différents stades d'altération $(g)$ et quartz $(q)$. La flèche montre une particule de verre altérée, surtout composée de gibbsite, $B-C$ : détail de la particule de verre gibbsitique au centre de A (C: centre de B). Selon l'analyse de dispersion d'énergie, la partie illustrée sur les micrographes est un mélange de gibbsite et de métahalloysite; le rapport gibbsite/métahalloysite est de 1/3. La proportion de composés de fer est de $10 \%$. 

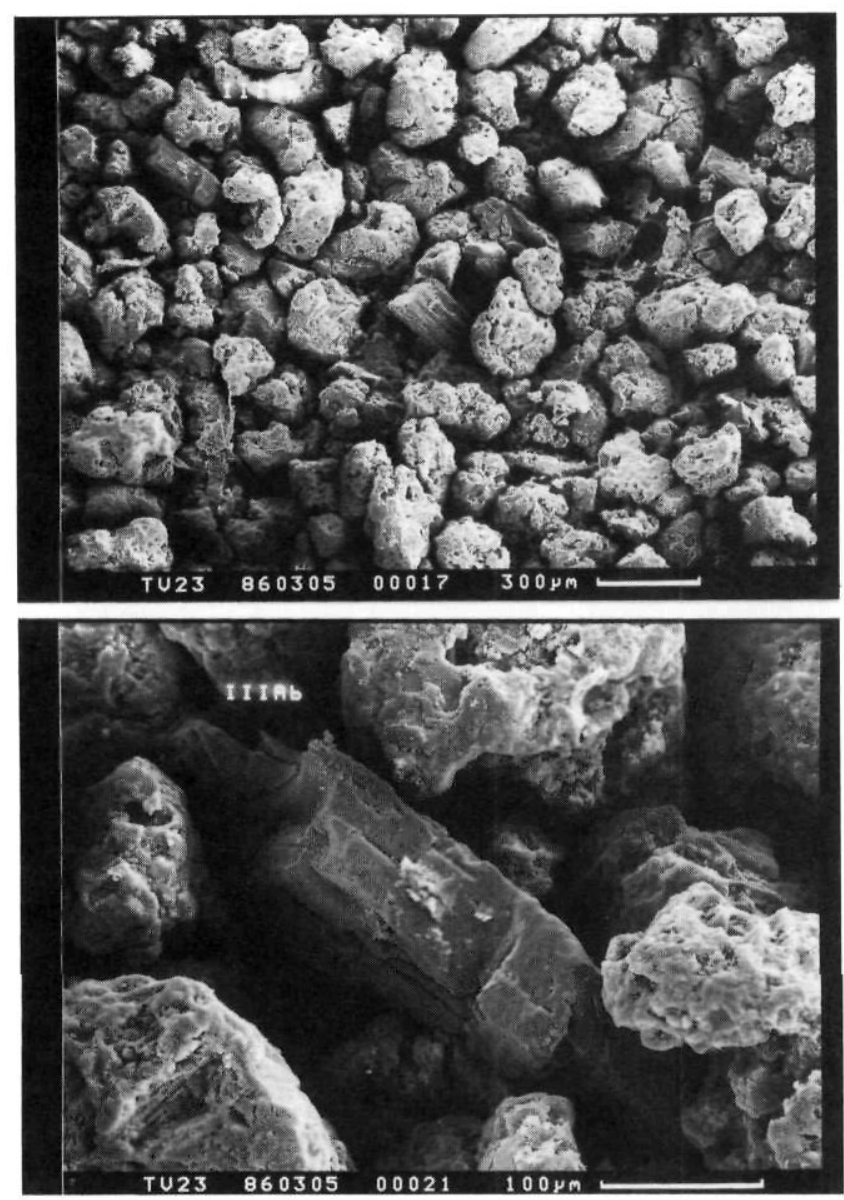

FIGURE 9. A: SEM micrograph of volcanic ash in the IIIAb horizon of the post-Teleki paleosol. For the mineralogy of this sample see Figure 3. Even grains that occur more or less unweathered under the petrographic microscope, show surficial transformation to metahalloysite and a varying proportion of iron and manganese compounds, when studied by means of the SEM and energy dispersive analysis. In the centre grain of weathered amphibole. B: detail of A (above left) alkali feldspar showing initial dissolution parallel to cleavage planes. C-D: formation of tubular metahalloysite on volcanic glass particle of the IIIAb horizon; inclusion of strongly etched alkali feldspar.

largely subangular to subrounded. The differences in percentages of feldspar may be related to weathering effects, since the grains analyzed by SEM in the pre-Teleki paleosol showed higher corrosion and dissolution effects.

The mixed loesses and tephras in both the post-Teleki (Unit I) and pre-Teleki (Unit III) paleosols indicate a high amount of aeolian activity between glaciations. This is further substantiated by the presence of glacially-crushed quartz in the loesses along with angular and subangular feldspar grains (including some nepheline) which were probably redistributed locally by aeolian processes.

\section{PALEOPEDOLOGICAL HISTORY}

The two main paleosol units are distinctly different with regard to their primary lithologies and with respect to the mineralogy to their weathering products. Whereas halloysite/
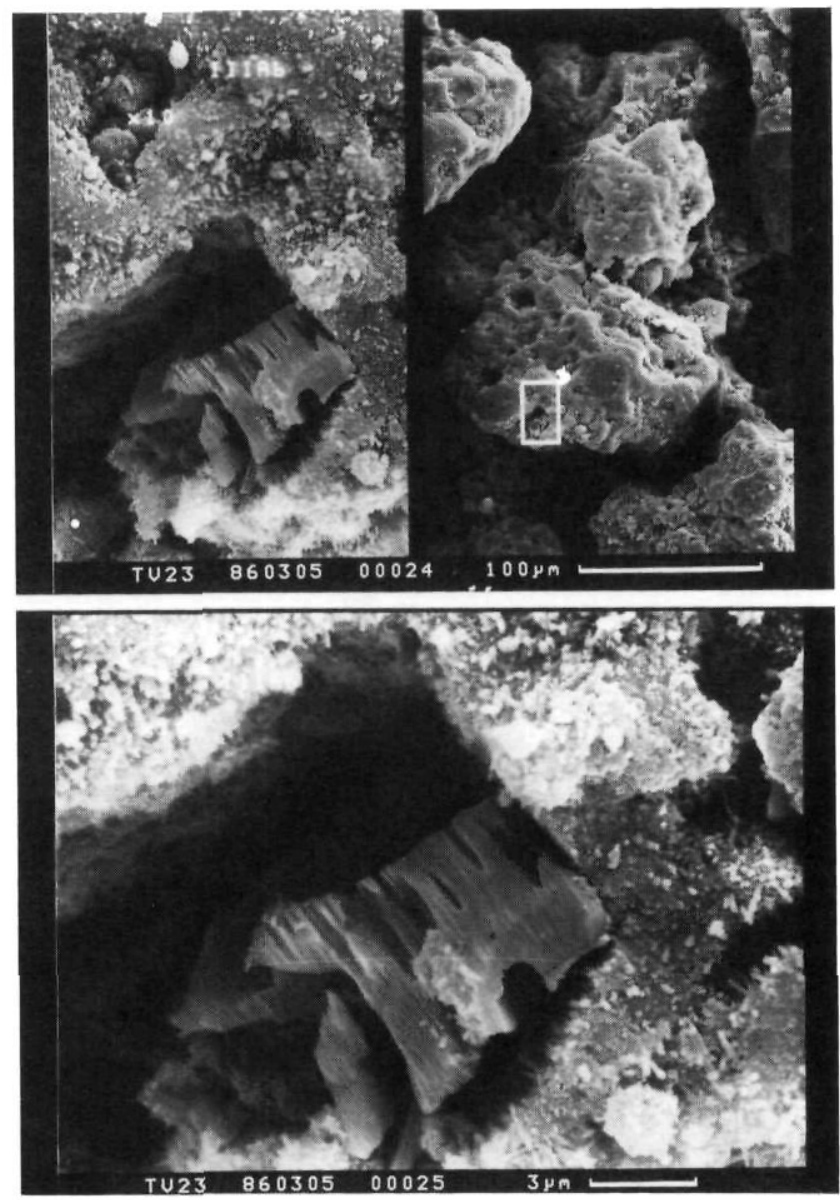

A: micrographe de cendre volcanique dans l'horizon IIIAb du paléosol post-Teleki. Voir la figure 3 pour la minéralogie de l'échantillon. Même les grains qui paraissent plus ou moins altérés au microscope pétrographique montrent des transformations superficielles en métahalloysite et des proportions variables de composés de fer et de manganèse, lorsque l'on en fait l'étude par le microscope électronique à balayage et l'analyse de dispersion d'énergie. Au centre, grain d'amphibole inaltéré; B: détail de A (supérieur gauche), feldspath alcalin qui montre des signes de dissolution parallèle au plan de clivage, $C$-D: formation de métahalloysite tubulaire sur une particule de verre volcanique dans l'horizon IIIAb; inclusion de feldspath alcalin très corrodé.

metahalloysite occurs in both paleosols, gibbsite was only found in the post-Teleki paleosol. This is noteworthy because gibbsite indicates even more intensive leaching conditions than halloysite-metahalloysite. On average the higher glass content in the fine and very fine sand fractions of the preTeleki paleosol probably corresponds to a higher content of volcanic ash in this paleosol. During the transformation of volcanic (especially vitric) tuffs, silica may be released to the pore solutions. Therefore, a higher content of volcanic ash, combined with lower permeability (higher clay content in preTeleki paleosol, see Figure 3) might have prevented the formation of gibbsite, or even assisted in the transformation of gibbsite to metahalloysite.

As mentioned above the pre-Teleki paleosol shows a considerably higher clay content than the post-Teleki paleosol (see e.g. Mahaney, 1982a). With the exception of horizons All $(25 \%)$ and IIIAb $(21 \%)$ the mean clay content $(<4 \mu \mathrm{m})$ of 

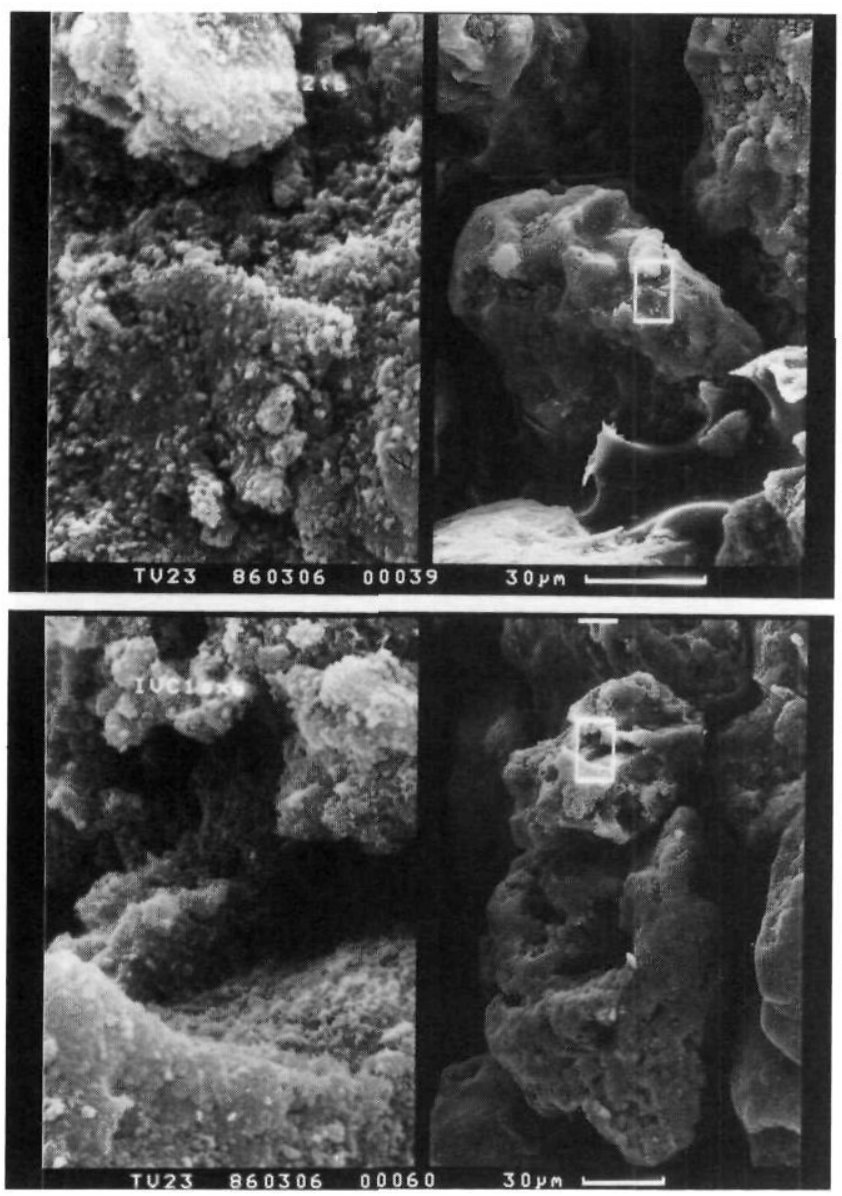

FIGURE 10. A: SEM micrograph showing a particle of Fe-Mn-rich opaque glass in the pre-Teleki soil horizon IIIB22tb with initial weathering. Metahalloysite and secondary iron and manganese compounds occur predominantly on the grain surface. B: Somewhat more intensively weathered opaque glass particle in the pre-Teleki soil horizon IVCloxb. Primary composition of the glass particle and weathering products similar to $\mathrm{A}$.

A: Micrographe d'une particule de verre opaque riche en Fe et $\mathrm{Mn}$ dans l'horizon IIIB22tb du sol pré-Teleki montrant un début d'altération. Des composés de fer et de manganèse apparaissent à la surface du grain. B: Particule de verre davantage altérée dans l'horizon IVCloxb du sol pré-Teleki. La composition primaire de la particule de verre et les produits de l'altération sont semblables à ceux de A.

the pre-Teleki soil is $84.5 \%$ (stand. dev. $11.0 \%$ ) and of the post-Teleki soil $66.2 \%$ (stand. dev. 9.8\%). In part this difference might result from the higher primary content of volcanic ash in the pre-Teleki paleosol, but it is also interpreted as a result of the greater age and/or more intensive weathering during the formation of this paleosol unit. Considering these aspects and the distribution of halloysite/metahalloysite and gibbsite we assume that the pre-Teleki paleosol was formed over a longer time but under less severe leaching conditions than the post-Teleki paleosol.

Differences in the weathering history of the two paleosol units are also suggested by observations of the feldspar grains. The average amount of clayey residual material on etched feldspar grain surfaces seems to be higher and the average feldspar etching somewhat more intensive in the pre-Teleki

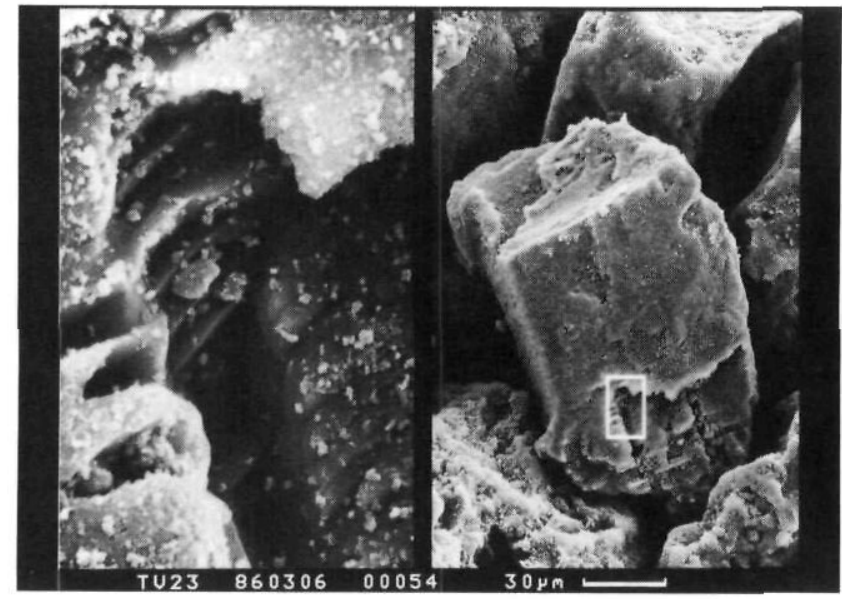

FIGURE 11. SEM micrograph of etched alkali feldspar in the preTeleki soil horizon IVCloxb; neoformation of clay minerals on the surface of the grain.

Micrographe d'un feldspath alcalin corrodé dans l'horizon IVCloxb du sol pré-Teleki; formation récente de minéraux d'argile à la surface du grain.

paleosol. Another important feature of TV23 is the variation of the weathering intensity within the two paleosol units. It gives the impression that these paleosols can be subdivided into sub-units which are the result of the interplay between soil-forming processes and the complex sedimentary history of pre- and post-Teleki deposits.

The B21t horizon in the post-Teleki paleosol and the IVCloxb horizon in the pre-Teleki paleosol are more intensively weathered than the horizons immediately above them (Fig. 3). It appears that this results from paleoweathering during the time when B21t and IVCloxb, respectively, formed the subaerially exposed sediments, i.e. before the younger parts of the main paleosol units were emplaced. Thus, the variation in weathering intensity might result from variations of complex factors, such as vegetation, paleoclimate, eolian (or generally sedimentary) and pyroclastic activity.

\section{AGE AND CORRELATION}

The IIIAb horizon (Fig. 3) yields a $>40,000$ yr BP (GaK$11319)$ infinite radiocarbon age. Samples of this horizon were collected "in the dark" for thermoluminescence (TL) age determination (see Mahaney, 1987), which yielded a date of $65,000 \pm 24,000$ yr BP (G. Berger, personal communication, 1984). The large standard deviation for this sample, coupled with inherent difficulties in dating volcanic feldspars with TL, and a tendency for TL dates to be considerably younger than radiocarbon dates, indicate that the IIIAb horizon was covered with Teleki Till $>100,000$ yrs ago. Thus, Teleki and pre-Teleki tills probably predate the last glaciation. Paleomagnetic determinations in both paleosol units yielded strong normal remanent magnetism indicating that both tills and that part of the upper loess in the post-Teleki paleosol probably formed sometime during the middle to lower Brunhes Chron (R. W. Barendregt, personal communication, 1986). Tills considered correlative with pre-Teleki tills on the eastern flank of Mount Kenya have middle Pleistocene (see Bowen, 1978, for time 
scale) stone tools on their surfaces (personal communication T. J. Charsley, 1985) which places their origin $>100,000 \mathrm{yr}$ BP.

\section{CONCLUSIONS}

Analytical data from the two paleosols show that pedological differences closely reflect differences in the lithology that result from modifications induced by paleoweathering conditions and interactions between sedimentation, (e.g. glacial, eolian and pyroclastic activity) paleoclimate, vegetation and water drainage. The advanced weathering effects in the pre-Teleki paleosol suggest considerable antiquity when compared with the post-Teleki paleosol. The pre-Teleki paleosol seems to have been formed over a longer time but under less intensive weathering conditions than the post-Teleki paleosol. Paleomagnetic determinations on these sediments, however, show that the entire sequence was formed $<730,000 \mathrm{yr} \mathrm{BP}$ at sometime in the lower to middle Brunhes Chron.

Quartz appears to be an indicator of aeolian activity, while high percentages of ferromagnetic minerals provide a signal for glaciation. Feldspar and volcanic glass vary in amount as a result of differential weathering in the two paleosols, and intensity of volcanic activity. Grains encrusted with hematite vary with respect to relative age, and are more common in the pre-Teleki paleosol. Sand grains with aeolian origins appear subrounded in shape, while glacial grains are subangular to angular (with quartz producing very angular grains on occasion but with few subparallel crushing planes). Tephra, resulting from pyroclastic activity, is subangular to subrounded reflecting probable transport of some grains by ice, followed by reworking through aeolian processes.

\section{ACKNOWLEDGEMENTS}

This research was supported by grants from the National Geographic Society (Nos. 1576.76, 2306, 81, 2672.83), the Natural Sciences and Engineering Research Council of Canada grant A9021, minor research grants from York University, and the University of Marburg. Field work was authorized by the Office of the President (Kenya Research permit OP 13/001/ 6C17/54), Kenya Parks and the Geological Survey of Kenya.

We are particularly indebted to Linda M. Mahaney for assistance in the field during 1976, 1983 and 1984, to students in the York University Mountain Geomorphology Field Schools in 1976 and 1983, and to Larry Gowland 1976 and 1983. Willie and Didi Curry, formerly of Naro Moru River Lodge, provided invaluable assistance and logistical support. Moreover, Phil Snyder (former Assistant Warden) and Bill Woodley (former Warden) and their rangers assisted with the 1976 field work. Mr. Fred Pertet (Ministry of Tourism) assisted in a similar way in 1983/84.

\section{REFERENCES}

Baker, B. H., 1967. Geology of the Mount Kenya Area. Geological Report No. 79, 78 p.

Bambauer, H. U., Taborszky, F., Trochim, H. D. and Tröger, W. E., 1971. Optische Bestimmung der gesteinsbildenden minerale. Teil 1, Bestimmungstabellen, Stuttgart (Schweizerbart), $188 \mathrm{p}$.
Birkeland, P. W., 1984. Soils and Geomorphology. Oxford, New York, $372 \mathrm{p}$.

Bouyoucos, G. J., 1962. Hydrometer method improved for making particle size analyses of soils. Agronomy Journal, 54: 464-465.

Bowen, D. Q., 1978. Quaternary Geology. Pergamon, Oxford, 221 p.

Coe, M. J., 1967. The Ecology of the Alpine Zone of Mt. Kenya. Junk, The Haque, $136 \mathrm{p}$.

Coetzee, J. A., 1967. Pollen analytical studies in East and Southern Africa. Palaeocology of Africa, 3, $146 \mathrm{p}$.

Day, P., 1965. Particle fractionation and particle size analysis, p. 545567. In Methods of Soil Analysis. American Society of Agronomy, Madison.

Dejou, J., Guyot, U. and Robert, M., 1977. Évolution superficielle des roches cristallines et cristallophyliennes dans les régions tempérées. Institut national de recherche en agronomie, Paris, $464 \mathrm{p}$.

Eslinger, E. V., Mayer, L. M., Durst, T. L., Hower, J. and Savin S. M., 1973. An X-ray technique for distinguishing between detrital and secondary quartz in the fine-grained fraction of sedimentary rocks. Journal of Sedimentary Petrology, 43: 540-543.

Folk, R. L., 1968. Petrology of Sedimentary Rocks. Hamphill Press, Austin, $170 \mathrm{p}$.

Hedberg, O., 1964. Features of Afroalpine Plant Ecology. Almquist \& Wiksells, Uppsala, $144 \mathrm{p}$.

Heiken, G., 1972. Morphology and petrography of volcanic ashes. Geological Society of America Bulletin, 83: 1961-1988.

Höller, H., Kolmer, H. and Wirsching, U., 1976. Chemische Untersuchungen der Umwandlung glasiger Tuffe in Montmorillonit und Kaolinit-Minerale. Neus Jahrbuch für Mineralogie, Monatshefte 1976: 456-466.

Kirkman, J. H., 1975. Clay mineralogy of some tephra beds of Rotorua area, North Island, New Zealand. Clay Minerals, 10: 437-449.

Mahaney, W. C., 1972. Late Quaternary history of the Mount Kenya Afroalpine area, East Africa, p. 139-142. In Palaecology of Africa, 6.

1979. Quaternary stratigraphy of Mount Kenya: A reconnaissance, p. 163-170. In E. M. Van Zinderen Bakker and J. A. Coetzee, ed., Palaeocology of Africa, 11.

1981. Paleoclimate reconstructed from paleosols: Evidence from the Rocky Mountains and East Africa, p. 227-247. In W. C. Mahaney, ed., Quaternary Paleoclimate. Geoabstracts, Norwich.

1982. Chronology of glacial deposits on Mount Kenya, East Africa, p. 25-43. In E. M. Van Zinderen Bakker and J. A. Coetzee, ed., Palaecology of Africa, 14.

1984a. Soils of the Mount Kenya area, their formation, ecological and agricultural significance (with soil map, scale: 1: 125,000): Discussion. Mountain Research and Development, 4: 284-285.

1984b. Loess in Pleistocene soils on Mount Kenya, East Africa. Loess Letter Supplement (Univ. of Waterloo, Dept. of Earth Sciences), 6, $20 \mathrm{p}$.

1984c. Radiometric dating of Quaternary glacial and nonglacial deposits, Mount Kenya, East Africa. Report on Grant 2306.81 to National Geographic Society, Research Report Series.

1985. Late glacial and Holocene paleoclimate of Mount Kenya, East Africa. Zeitschift für Gletscherkunde und Glazialgeologie, B21: 203-211. 
1987. Quaternary geology of Mount Kenya. In W. C. Mahaney, ed., Quaternary and Environmental Research on East African Mountains, Balkema, Rotterdam (in press).

Mahaney, W. C. and Boyer, M. G., 1986. Microflora distributions in paleosols: A method for calculating the validity of radiocarbondated surfaces. Soil Science, 142: 100-107.

Nilsson, E., 1935. Traces of ancient changes of climate in East Africa. Geografiska Annaler, 1-2: 1-21.

Pedgley, D. E., 1966. Rainfall of Mount Kenya. Weather, 21: 176188.
Soil Survey Staff, 1951. Soil Survey Manual. U.S. Government Printing Office, Washington, D.C., 503 p.

1975. Soil Taxonomy. Agriculture Handbook 436, U.S. Department of Agriculture, Washington, D.C., 754 p.

Thompson, B. W., 1966. The mean annual rainfall of Mount Kenya. Weather, 21: 48-49.

Vortisch, W. B., Mahaney, W. C. and Fecher, K., 1987. Lithology and weathering in a paleosol sequence on Mount Kenya, E. Africa. Geologica et Paleontologica, 21: 245-255. 